Coevolution of Animals and Plants 
THIS PAGE INTENTIONALLY LEFT BLANK 
The Dan Danciger Publication Series 
THIS PAGE INTENTIONALLY LEFT BLANK 


\title{
Coevolution of \\ Animals and Plants
}

\author{
Symposium V
}

First International Congress of

Systematic and Evolutionary

Biology

Boulder, Colorado

August 1973

Edited by

\section{Lawrence E. Gilbert \\ and}

Peter H. Raven 
For reasons of economy and speed this volume has been printed from cameraready copy furnished by the Editors, who assume full responsibility for its contents.

International Standard Book Number 0-292-71031-3 Library of Congress Catalog Card Number 74-11787 Copyright (C) 1975 by the University of Texas Press Al1 rights reserved Printed in the United States of America 